\title{
Synthesis and Fundamental Properties of Cu-Based Bulk Glassy Alloys in Binary and Multi-component Systems
}

\author{
Akihisa Inoue $^{1}$, Wei Zhang ${ }^{2}$ and Junji Saida ${ }^{3}$ \\ ${ }^{1}$ Institute for Materials Research, Tohoku University, Sendai 980-8577, Japan \\ ${ }^{2}$ Japan Science and Technology Agency, Sendai 980-8577, Japan \\ ${ }^{3}$ Center for Interdisciplinary Research, Tohoku University, Sendai 980-8578, Japan
}

A glassy phase containing cubic phase particles with a size of $3-5 \mathrm{~nm}$ was formed in cast $\mathrm{Cu}_{60} \mathrm{Zr}_{30} \mathrm{Ti}_{10}$ and $\mathrm{Cu}_{60} \mathrm{Hf}_{30} \mathrm{Ti}_{10}$ bulk alloys. The cubic phase is in a metastable state and its lattice parameter $\left(a_{0}\right)$ is $0.45 \mathrm{~nm}$ for the former alloy and $0.51 \mathrm{~nm}$ for the latter. These bulk alloys exhibit good mechanical properties of 2000-2130 MPa for tensile strength $\left(\sigma_{\mathrm{t}, \mathrm{f}}\right), 2060-2160 \mathrm{MPa}$ for compressive strength $\left(\sigma_{\mathrm{c}, \mathrm{f}}\right)$ and $0.008-0.017$ for compressive plastic strain $\left(\varepsilon_{\mathrm{c}, \mathrm{p}}\right)$. The temperature interval of the supercooled liquid (SL) region prior to crystallization is $37 \mathrm{~K}$ for $\mathrm{Cu}_{60} \mathrm{Zr}_{30} \mathrm{Ti}_{10}$ and $67 \mathrm{~K}$ for $\mathrm{Cu}_{60} \mathrm{Hf}_{30} \mathrm{Ti}_{10}$. The primary crystallization occurred by precipitation of cubic CuZr $\left(a_{0}=0.35 \mathrm{~nm}\right)$ in a diffusion-controlled growth mode of nuclei and an orthorhombic $\mathrm{Cu}_{8} \mathrm{Hf}_{3}$ phase in an interface diffusion-controlled growth of nuclei with decreasing nucleation rate. The difference in the precipitation modes is interpreted to be the origin of the difference in the SL region. Furthermore, the addition of $\mathrm{Al}$ to $\mathrm{Cu}-\mathrm{Zr}$ and $\mathrm{Cu}$-Hf alloys caused the formation of a glassy single phase in the rod form with diameters up to at least $3 \mathrm{~mm}$, though bulk glassy alloy rods with critical diameters up to $1.5 \mathrm{~mm}$ and $\sigma_{\mathrm{c}, \mathrm{f}}$ of $1920-2260 \mathrm{MPa}$ were formed in $\mathrm{Cu}-\mathrm{Zr}$ and $\mathrm{Cu}-\mathrm{Hf}$ binary systems. The ternary bulk glassy alloys exhibited high $\sigma_{\mathrm{c}, \mathrm{f}}$ of $2100-2370 \mathrm{MPa}$ with $\varepsilon_{\mathrm{c}, \mathrm{p}}$ of $0.002-0.006$. The addition of Pd, Pt, $\mathrm{Ag}$ or $\mathrm{Au}$ increased $\Delta T_{\mathrm{x}}$ and a large $\Delta T_{\mathrm{x}}$ of $102-110 \mathrm{~K}$ was obtained for the $\mathrm{Cu}-\mathrm{Hf}-\mathrm{Al}-\mathrm{M}(\mathrm{M}=\mathrm{Pd}$ or $\mathrm{Ag})$ glassy alloys. The synthesis of Cu-based bulk glassy alloys with good mechanical properties and large $\Delta T_{\mathrm{X}}$ in glassy single, and mixed glassy and cubic phase states, is important for future applications of bulk glassy alloys.

(Received December 4, 2003; Accepted February 20, 2004)

Keywords: copper-based alloy, bulk glassy alloy, supercooled liquid, mechanical property, crystallization, microstructure, TEM

\section{Introduction}

It is known that high-strength bulk glassy alloys are obtained in $\mathrm{Zr}$ - and Pd-based alloy systems by the copper mold casting and water quenching techniques. ${ }^{1-4)}$ It is important to develop a new bulk glassy alloy with high strength and good ductility in late transition-metal based alloys such as $\mathrm{Fe}-$, $\mathrm{Co}-$, Ni- and $\mathrm{Cu}$-based systems because they are expected to have much higher mechanical strength. A number of bulk glassy alloys developed to date include $\mathrm{Cu}$ as one of the major solute elements, as exemplified by $\mathrm{Zr}-\mathrm{Al}-$ $\mathrm{Cu}, \mathrm{Zr}-\mathrm{Al}-\mathrm{Ni}-\mathrm{Cu}, \mathrm{Zr}-\mathrm{Ti}-\mathrm{Ni}-\mathrm{Cu}-\mathrm{Be}$ and Ti-Zr-Ni-Cu-Sn glassy alloys. ${ }^{1-4)}$ Subsequently, some bulk glassy alloys containing a large amount of $\mathrm{Cu}$ (40 to 45 at\%) have also been developed. ${ }^{5}$ ) However, no data have been available on the formation of $\mathrm{Cu}$-based bulk glassy alloys with more than 50 at $\% \mathrm{Cu}$. In 2000, Inoue et al. succeeded for the first time in synthesizing $\mathrm{Cu}$-based bulk glassy alloys in $\mathrm{Cu}-\mathrm{Zr}-\mathrm{Ti}$, ${ }^{6,7)} \mathrm{Cu}$ $\mathrm{Zr},{ }^{7,8)} \mathrm{Cu}-\mathrm{Hf}-\mathrm{Ti}^{7,9)} \mathrm{Cu}-\mathrm{Hf}^{7,8)}$ and $\mathrm{Cu}-\mathrm{Zr}-\mathrm{Hf}-\mathrm{Ti}^{10)}$ systems. It has been reported that glassy alloy rods with diameters up to $1.5 \mathrm{~mm}$ are formed even in $\mathrm{Cu}-\mathrm{Zr}$ and $\mathrm{Cu}-\mathrm{Hf}$ binary alloy systems. Multi-component $\mathrm{Cu}$-based bulk glassy alloys have been prepared in diameters up to $4 \mathrm{~mm}$, and exhibited high fracture strength of $2000-2160 \mathrm{MPa}$ as well as significant plastic strain of 0.008 to $0.017,,^{6-8,10)}$ much larger than observed in other bulk glassy alloys. ${ }^{1-4)}$ Subsequent study has demonstrated that the $\mathrm{Cu}$-based bulk glassy alloys exhibiting good mechanical properties consist of a glassy phase containing high volume fractions of metastable cubic phase with a size of $3-5 \mathrm{~nm} .{ }^{11,12)}$ Thus, the new Cu-based glassy alloys in $\mathrm{Cu}-\mathrm{Zr}-\mathrm{Ti}$ and $\mathrm{Cu}-\mathrm{Hf}-\mathrm{Ti}$ systems are classified as a new type of nanocrystal-dispersed bulk glassy alloy. $\mathrm{Cu}$ based bulk glassy alloys without any second phase have also been synthesized in $\mathrm{Cu}-\mathrm{Zr}-\mathrm{Al}$ and $\mathrm{Cu}-\mathrm{Hf}-\mathrm{Al}$ based systems.
This paper aims to review our recent results on the formation, thermal stability, mechanical properties and corrosion resistance of bulk glassy single phase alloys and nanocrystaldispersed glassy alloys in $\mathrm{Cu}$-based binary and multicomponent systems in which $\mathrm{Cu}$ exceeds 50 at\%.

\section{Formation and Properties of Binary Bulk Glassy Alloys}

Figure 1 shows $\mathrm{X}$-ray diffraction patterns of $\mathrm{Cu}_{60} \mathrm{Zr}_{40}$, $\mathrm{Cu}_{45} \mathrm{Zr}_{55}, \mathrm{Cu}_{60} \mathrm{Hf}_{40}$ and $\mathrm{Cu}_{55} \mathrm{Hf}_{45}$ glassy alloy rods with

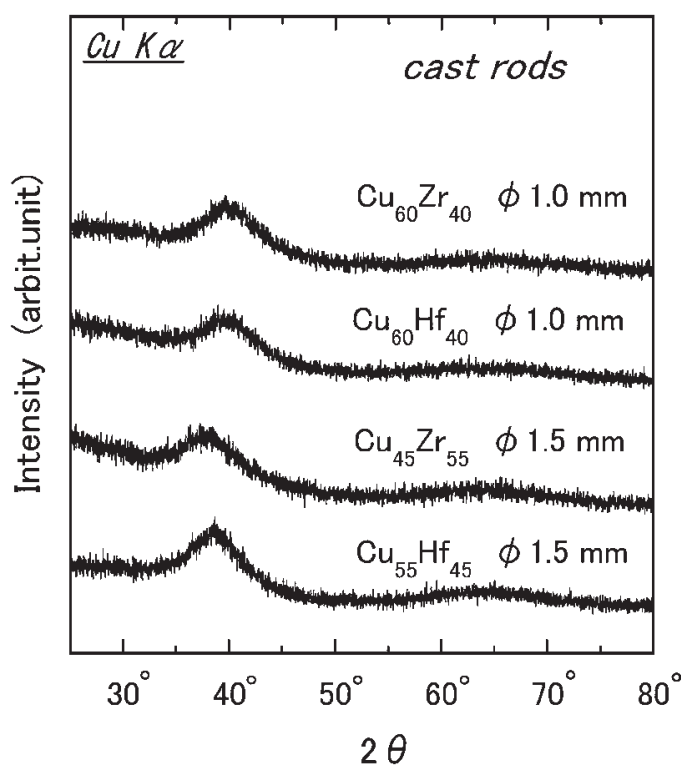

Fig. 1 X-ray diffraction patterns of $\mathrm{Cu}_{60} \mathrm{Zr}_{40}, \mathrm{Cu}_{45} \mathrm{Zr}_{55}, \mathrm{Cu}_{60} \mathrm{Hf}_{40}$ and $\mathrm{Cu}_{55} \mathrm{Hf}_{45}$ glassy alloy rods with diameters of 1.0 and $1.5 \mathrm{~mm}$. 


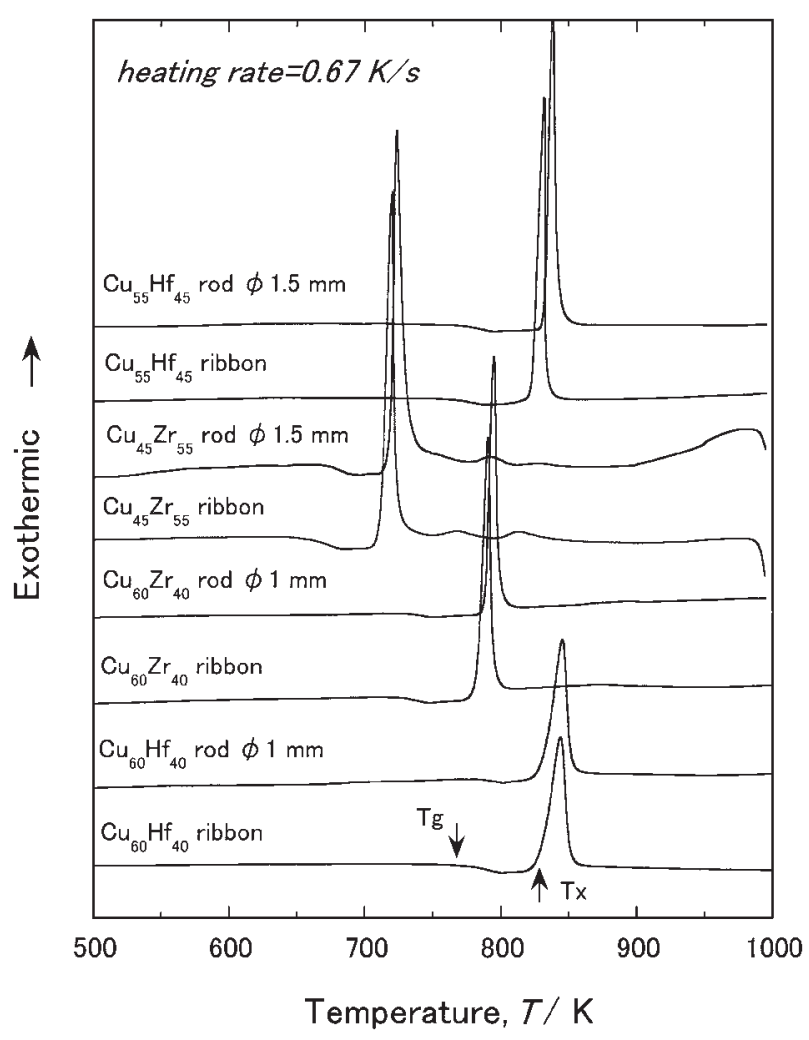

Fig. 2 DSC curves of $\mathrm{Cu}_{60} \mathrm{Zr}_{40}, \mathrm{Cu}_{45} \mathrm{Zr}_{55}, \mathrm{Cu}_{60} \mathrm{Hf}_{40}$ and $\mathrm{Cu}_{55} \mathrm{Hf}_{45}$ glassy alloy rods with diameters of 1.0 and $1.5 \mathrm{~mm}$. The data of the corresponding melt-spun glassy alloy ribbons are also shown for comparison.

diameters of 1.0 and $1.5 \mathrm{~mm}$ produced by the copper mold casting method. ${ }^{8)}$ Only broad peaks are seen in the diffraction patterns, indicating that a glassy phase without crystalline phase is formed even for the $\mathrm{Cu}-\mathrm{Zr}$ and $\mathrm{Cu}-\mathrm{Hf}$ binary alloy rods. With the aim of confirming the formation of nearly the same glassy phase as that for melt-spun glassy alloy ribbons, DSC curves of the $\mathrm{Cu}_{60} \mathrm{Zr}_{40}, \mathrm{Cu}_{45} \mathrm{Zr}_{55}, \mathrm{Cu}_{60} \mathrm{Hf}_{40}$ and $\mathrm{Cu}_{55} \mathrm{Hf}_{45}$ glassy alloy rods are shown in Fig. 2. The data for the melt-spun glassy alloy ribbons are also shown for comparison. The $T_{\mathrm{g}}$ and $T_{\mathrm{x}}$ are $733 \mathrm{~K}$ and $791 \mathrm{~K}$, respectively, for the $\mathrm{Cu}_{60} \mathrm{Zr}_{40}$ alloy rod, $669 \mathrm{~K}$ and $719 \mathrm{~K}$, for the $\mathrm{Cu}_{45} \mathrm{Zr}_{55}$ alloy rod, $773 \mathrm{~K}$ and $827 \mathrm{~K}$, for the $\mathrm{Cu}_{60} \mathrm{Hf}_{40}$ alloy rod and $771 \mathrm{~K}$ and $830 \mathrm{~K}$, for the $\mathrm{Cu}_{55} \mathrm{Hf}_{45}$ alloy rod, nearly the same as those for $\mathrm{Cu}_{60} \mathrm{Zr}_{40}, \mathrm{Cu}_{45} \mathrm{Zr}_{55}, \mathrm{Cu}_{60} \mathrm{Hf}_{40}$ and $\mathrm{Cu}_{55} \mathrm{Hf}_{45}$ glassy alloy ribbons. The liquidus temperature $\left(T_{1}\right)$ was measured as $1198 \mathrm{~K}$ for $\mathrm{Cu}_{60} \mathrm{Zr}_{40}, 1206 \mathrm{~K}$ for $\mathrm{Cu}_{45} \mathrm{Zr}_{55}$, $1290 \mathrm{~K}$ for $\mathrm{Cu}_{60} \mathrm{Hf}_{40}$ and $1295 \mathrm{~K}$ for $\mathrm{Cu}_{55} \mathrm{Hf}_{45}$ and hence the $T_{\mathrm{g}} / T_{1}$ values of their alloys were $0.61,0.56,0.60$ and 0.59 , respectively. These $T_{\mathrm{g}} / T_{1}$ values indicate that the three binary alloys have high glass-forming ability leading to the formation of bulk glassy alloy rods by the copper mold casting method.

Figure 3 shows nominal compressive stress-strain curves of the $\mathrm{Cu}_{60} \mathrm{Zr}_{40}, \mathrm{Cu}_{45} \mathrm{Zr}_{55}, \mathrm{Cu}_{60} \mathrm{Hf}_{40}$ and $\mathrm{Cu}_{55} \mathrm{Hf}_{45}$ glassy alloy rods. ${ }^{8)}$ The Young's modulus $(E)$, fracture strength $\left(\sigma_{\mathrm{f}}\right)$ and plastic elongation $\left(\varepsilon_{\mathrm{c}, \mathrm{p}}\right)$ are $107 \mathrm{GPa}, 1920 \mathrm{MPa}$ and $0.2 \%$, respectively, for the $\mathrm{Cu}_{60} \mathrm{Zr}_{40}$ alloy rod, $102 \mathrm{GPa}$, $1880 \mathrm{MPa}$ and $1.5 \%$, for the $\mathrm{Cu}_{45} \mathrm{Zr}_{55}$ alloy rod, $120 \mathrm{GPa}$, $2245 \mathrm{MPa}$ and $0.4 \%$, for the $\mathrm{Cu}_{60} \mathrm{Hf}_{40}$ alloy rod and $121 \mathrm{GPa}$, $2260 \mathrm{MPa}$ and $2.2 \%$, for the $\mathrm{Cu}_{55} \mathrm{Hf}_{45}$ alloy rod. Furthermore,

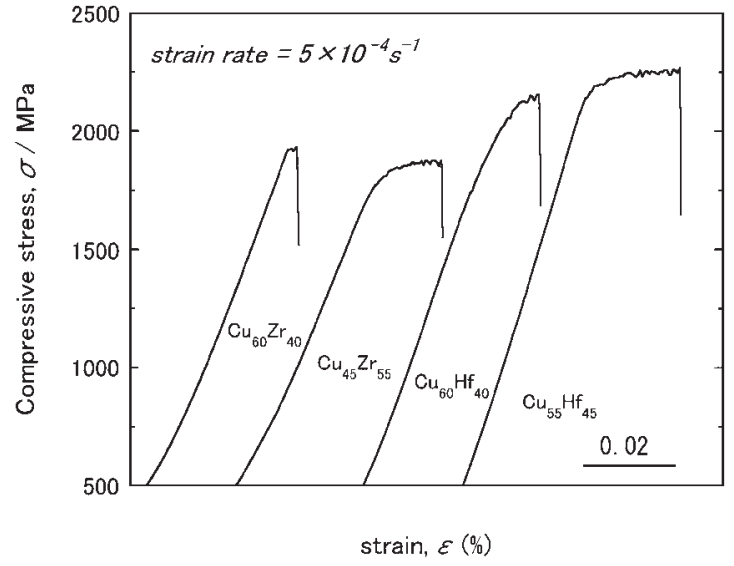

Fig. 3 Compressive stress-strain curves of $\mathrm{Cu}_{60} \mathrm{Zr}_{40}, \mathrm{Cu}_{45} \mathrm{Zr}_{55}, \mathrm{Cu}_{60} \mathrm{Hf}_{40}$ and $\mathrm{Cu}_{55} \mathrm{Hf}_{45}$ glassy alloy rods with diameters of 1.0 and $1.5 \mathrm{~mm}$.
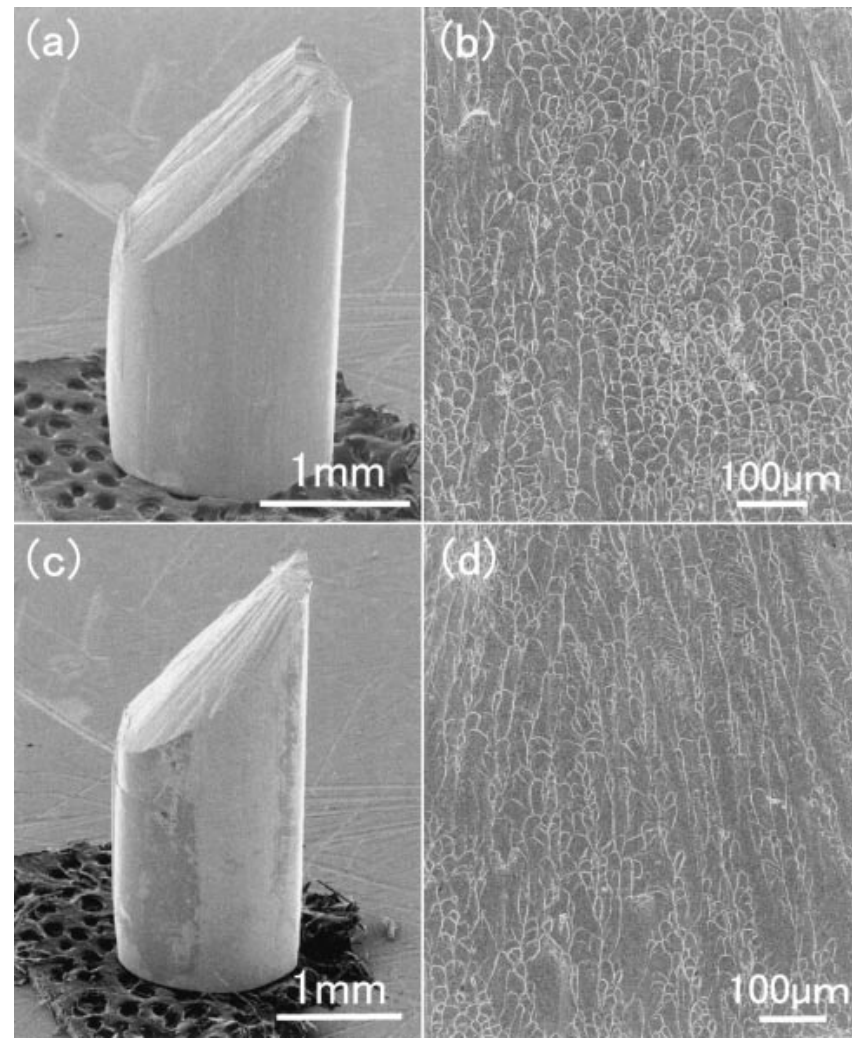

Fig. 4 Fracture surface morphology of $\mathrm{Cu}_{45} \mathrm{Zr}_{55}(\mathrm{a}, \mathrm{b})$ and $\mathrm{Cu}_{55} \mathrm{Hf}_{45}(\mathrm{c}, \mathrm{d})$ glassy alloy rods fractured in a uniaxial compressive deformation mode.

it was observed that the $\mathrm{Cu}_{45} \mathrm{Zr}_{55}$ and $\mathrm{Cu}_{55} \mathrm{Hf}_{45}$ alloy rods exhibit distinct plastic elongation of $1.5-2.2 \%$. Figure 4 shows the fracture surface morphology of the $\mathrm{Cu}_{45} \mathrm{Zr}_{55}$ and $\mathrm{Cu}_{55} \mathrm{Hf}_{45}$ alloy rods. The fracture occurs along the maximum shear stress plane which is inclined by about 45 degrees to the direction of compressive applied load. In addition, the fracture surface consists mainly of vein patterns elongated in the direction of shear sliding. These deformation and fracture behaviors indicate that the $\mathrm{Cu}-\mathrm{Zr}$ and $\mathrm{Cu}-\mathrm{Hf}$ glassy alloy rods have good mechanical properties combined with fracture strength over $2000 \mathrm{MPa}$ and distinct plastic elongation. 
It has been reported that the addition of $1-5$ at $\% \mathrm{Pd}$ to $\mathrm{Cu}_{30} \mathrm{Zr}_{70}{ }^{13)}$ and $\mathrm{Cu}_{60} \mathrm{Zr}_{30} \mathrm{Ti}_{10}{ }^{14)}$ causes the precipitation of an icosahedral phase as a primary crystallization phase. The icosahedral phase has a fine particle size of $3-50 \mathrm{~nm}$ and precipitates very homogeneously in the glassy matrix. In addition, we have confirmed the absence of any appreciable segregation of elemental $\mathrm{Cu}$ and $\mathrm{Zr}$ at the first neighboring position in the radial distribution function (RDF) profile of $\mathrm{Cu}_{30} \mathrm{Zr}_{70}$ glassy alloy. ${ }^{15)}$ That is, the local atomic configuration is different from those for the corresponding equilibrium compounds. These earlier data have been interpreted on the assumption that the Cu-based glassy alloys have a unique glassy structure consisting mainly of shortrange icosahedral atomic configurations. Furthermore, the melt-metal type alloys with three component rules such as $\mathrm{Zr}-\mathrm{Cu}-\mathrm{Al}$ and $\mathrm{Zr}-\mathrm{Ni}-\mathrm{Al}$ systems have an unique structure with the features of (1) highly dense-packed atomic configuration, (2) new local atomic configuration, and (3) longrange homogeneity with attractive interaction, ${ }^{4)}$ being consistent with the formation of a short-range icosahedral atomic configuration. Based on these earlier data, it may be also concluded that the high glass-forming ability of the $\mathrm{Cu}-\mathrm{Zr}$ binary alloys originates from the formation of a unique local atomic configuration such as an icosahedral atomic configuration which is different from the local structure of the corresponding equilibrium compounds. It is well known that the icosahedral type short-range atomic configuration is one of the favorable glassy structures leading to enhancement of stability of the supercooled liquid against crystallization. ${ }^{13)}$

\section{Formation and Thermal Stability of Multi-compo- nent Bulk Glass Alloys}

Figure 5 shows $\mathrm{X}$-ray diffraction patterns of $\mathrm{Cu}-\mathrm{Zr}-\mathrm{Ti}$ and

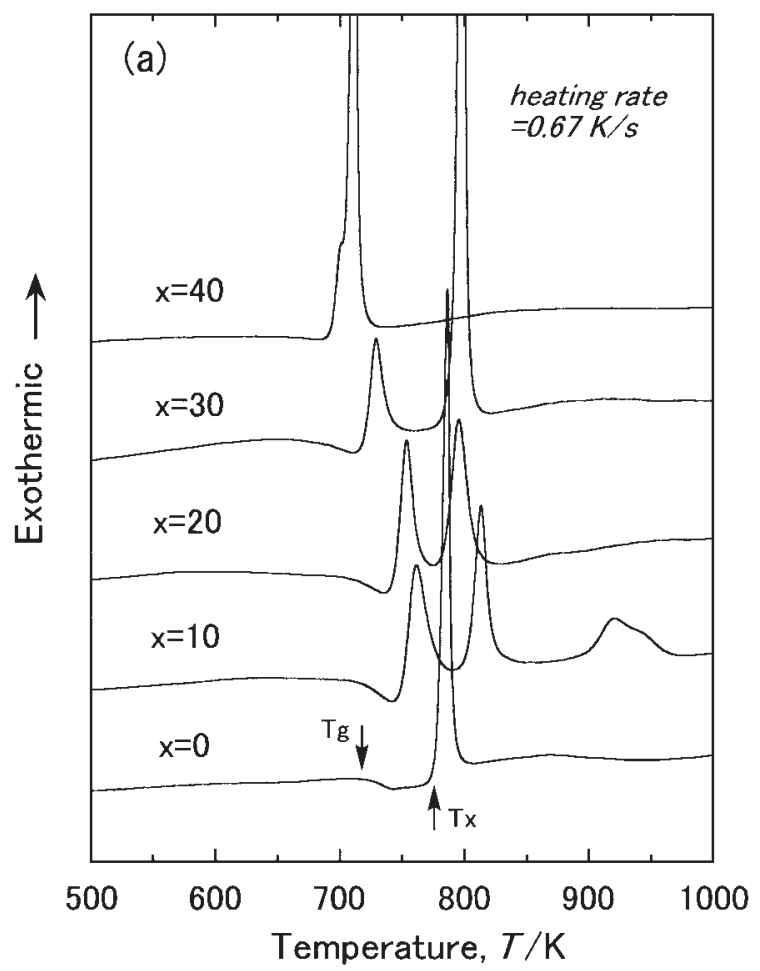

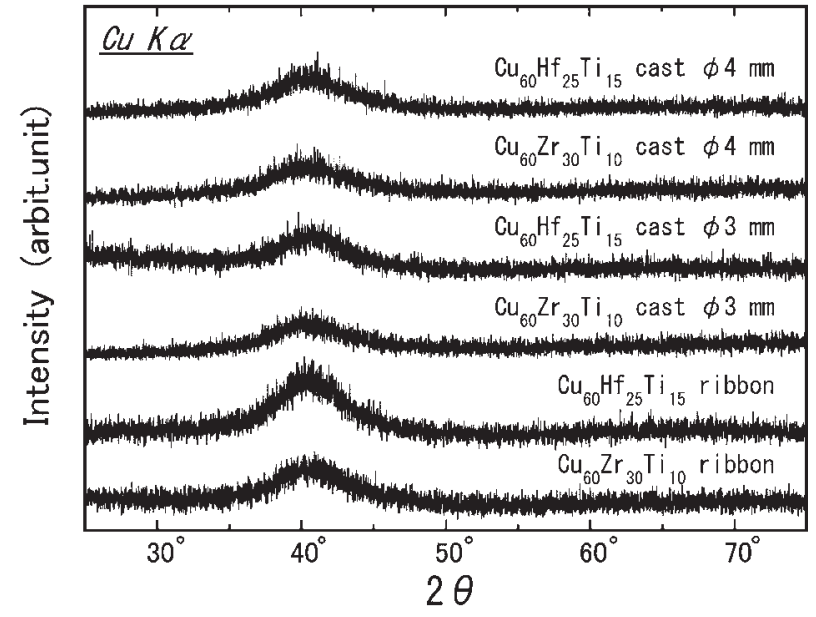

Fig. 5 X-ray diffraction patterns of $\mathrm{Cu}_{60} \mathrm{Zr}_{30} \mathrm{Ti}_{10}$ and $\mathrm{Cu}_{60} \mathrm{Hf}_{25} \mathrm{Ti}_{15}$ glassy alloy rods with diameters of 3 and $4 \mathrm{~mm}$ produced by copper mold casting. The data of the melt-spun glassy alloy ribbons are also shown for comparison.

Cu-Hf-Ti alloy rods with diameters of 3 and $4 \mathrm{~mm}$ prepared by copper mold casting, together with data of melt-spun alloy ribbons. All the alloy rods have a broad peak without any crystalline peaks, indicating the formation of predominantly a single glassy phase. Their glassy alloy rods have a smooth outer surface without the concavities and ruggedness that would result from the precipitation of a crystalline phase, and show good metallic luster. The Cu-based ternary alloys in $\mathrm{Cu}_{60} \mathrm{Zr}_{40-x} \mathrm{Ti}_{x}$ and $\mathrm{Cu}_{60} \mathrm{Hf}_{40-x} \mathrm{Ti}_{x}$ systems have $T_{\mathrm{g}} / T_{1}$ above 0.60 over a wide range of compositions from $0-25$ at $\% \mathrm{Ti}$. The maximum values $(0.63)$ of $T_{\mathrm{g}} / T_{1}$ in the vicinity of 20 at $\% \mathrm{Ti}$ are due to the decrease in $T_{1}$. Figure 6 shows DSC curves of the $\mathrm{Cu}_{60} \mathrm{Zr}_{40-x} \mathrm{Ti}_{x}$ and $\mathrm{Cu}_{60} \mathrm{Hf}_{40-x} \mathrm{Ti}_{x}$ glassy alloys,

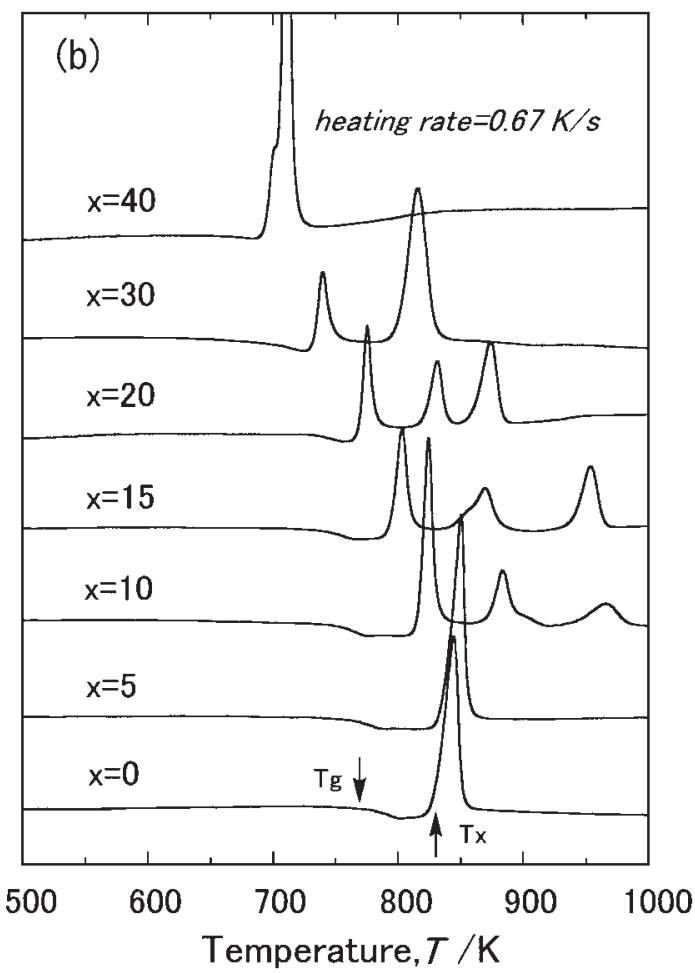

Fig. 6 Differential scanning calorimetric (DSC) curves of $\mathrm{Cu}_{60} \mathrm{Zr}_{40-x} \mathrm{Ti}_{x}$ (a) and $\mathrm{Cu}_{60} \mathrm{Hf}_{40-x} \mathrm{Ti}_{x}$ (b) $(x=0$ to 40 at\%) glassy alloys. 


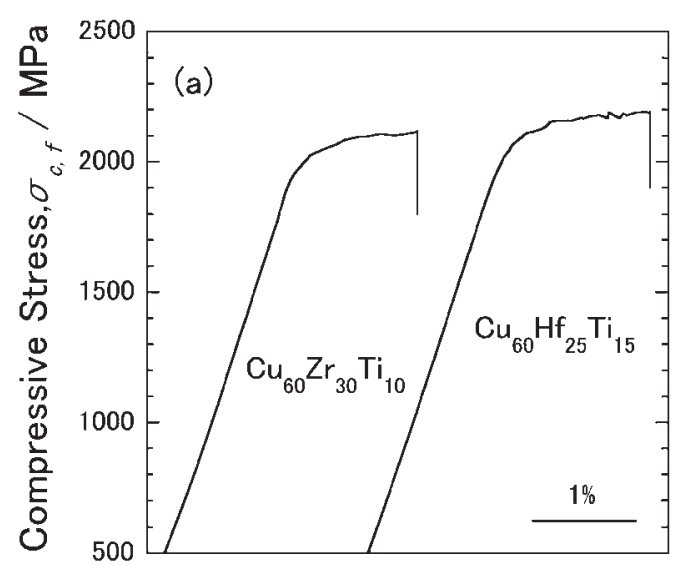

$\varepsilon(\%)$

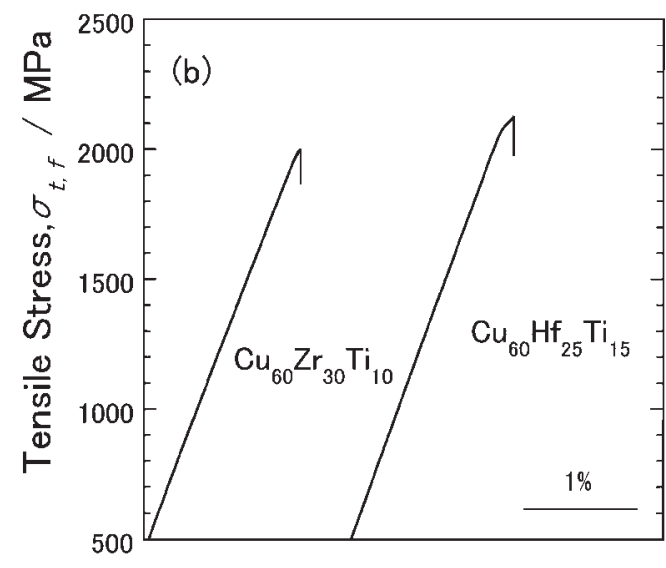

$\varepsilon(\%)$

Fig. 7 Nominal stress-strain curves of cast $\mathrm{Cu}_{60} \mathrm{Zr}_{30} \mathrm{Ti}_{10}$ and $\mathrm{Cu}_{60} \mathrm{Hf}_{25} \mathrm{Ti}_{15}$ glassy alloy rods. (a) compressive deformation mode, and (b) tensile deformation mode.

respectively. It can be seen that the $\mathrm{Cu}-\mathrm{Zr}$ - $\mathrm{Ti}$ alloys with high glass-forming ability do not show a large supercooled liquid region prior to crystallization, though the $\mathrm{Cu}-\mathrm{Hf}-\mathrm{Ti}$ alloys exhibit a rather large supercooled liquid region from 28 $78 \mathrm{~K}$. In addition, the $\mathrm{Cu}-\mathrm{Zr}$-Ti glassy alloys crystallize through multiple states, suggesting that the primary crystallization phase is in a metastable state. The strange phenomenon that the alloys without a large supercooled liquid region before crystallization exhibit a high glass-forming ability is investigated in more details later.

\section{Mechanical Properties and Corrosion Resistance}

The Cu-based glassy alloy rods exhibited good mechanical properties which have not been obtained in $\mathrm{Zr}-, \mathrm{Mg}-$ and lanthanide(Ln)-based bulk glassy alloys. ${ }^{1-4)}$ The Young's modulus $(E)$, yield strength $\left(\sigma_{\mathrm{y}}\right), \sigma_{\mathrm{t}, \mathrm{f}}, \sigma_{\mathrm{c}, \mathrm{f}}$ and $\varepsilon_{\mathrm{c}, \mathrm{p}}$ are $114 \mathrm{GPa}, 1785 \mathrm{MPa}, 2000 \mathrm{MPa}, 2150 \mathrm{MPa}$ and 0.012 , respectively, for $\mathrm{Cu}_{60} \mathrm{Zr}_{30} \mathrm{Ti}_{10}$ and $124 \mathrm{GPa}, 2040 \mathrm{MPa}$, $2130 \mathrm{MPa}, 2160 \mathrm{MPa}$ and 0.017 , for $\mathrm{Cu}_{60} \mathrm{Hf}_{25} \mathrm{Ti}_{15}$, as shown in Fig. 7. We have also reported that the addition of $\mathrm{Be}$ to $\mathrm{Cu}-$ $\mathrm{Zr}$-Ti alloy $\left(\mathrm{Cu}_{54} \mathrm{Zr}_{27} \mathrm{Ti}_{9} \mathrm{Be}_{10}\right)$ causes a further increase in the $E, \sigma_{\mathrm{y}}, \sigma_{\mathrm{t}, \mathrm{f}}$ and $\sigma_{\mathrm{c}, \mathrm{f}}$ to $146 \mathrm{GPa}, 2180 \mathrm{MPa}, 2450 \mathrm{MPa}$ and $2500 \mathrm{MPa}$, respectively, in conjunction with rather good plastic strain of 0.035 under a compressive applied load. ${ }^{16)}$ Although the supercooled liquid region defined by the difference between $T_{\mathrm{g}}$ and $T_{\mathrm{x}}, \Delta T_{\mathrm{x}}\left(=T_{\mathrm{x}}-T_{\mathrm{g}}\right)$, is as small as $37 \mathrm{~K}$ for $\mathrm{Cu}_{60} \mathrm{Zr}_{30} \mathrm{Ti}_{10}$, the addition of $\mathrm{Ni}$ or Co increases $\Delta T_{\mathrm{x}}$ to $60 \mathrm{~K}$ for $\left(\mathrm{Cu}_{0.6} \mathrm{Zr}_{0.3} \mathrm{Ti}_{0.1}\right)_{95} \mathrm{Ni}_{5}$ and $49 \mathrm{~K}$ for $\left(\mathrm{Cu}_{0.6} \mathrm{Zr}_{0.3} \mathrm{Ti}_{0.1}\right)_{96} \mathrm{Co}_{4} \cdot{ }^{17)}$ The $5 \% \mathrm{Ni}$ - and $4 \% \mathrm{Co}$-containing alloys also maintain high yield strength of about $1900 \mathrm{MPa}$. We further examined the effect of $\mathrm{Nb}$ on the mechanical properties of $\mathrm{Cu}-\mathrm{Zr}$-Ti-Nb glassy alloys. ${ }^{18)}$ The yield strength increases with increasing $\mathrm{Nb}$ content and the highest yield strength is $2050 \mathrm{MPa}$ for $\left(\mathrm{Cu}_{0.6} \mathrm{Zr}_{0.3} \mathrm{Ti}_{0.1}\right)_{91} \mathrm{Ni}_{5} \mathrm{Nb}_{4}$ alloy rod. The $\mathrm{Cu}-\mathrm{Zr}$-Ti-Nb glassy alloys exhibit good corrosion resistance in various chemical aqueous solutions such as $1 \mathrm{NHCl}, 3 \% \mathrm{NaCl}$ and $1 \mathrm{NH}_{2} \mathrm{SO}_{4}+0.001 \mathrm{NNaCl}^{19)}$ It has been clarified that the improvement of corrosion resistance by the addition of $\mathrm{Nb}$ is mainly due to an increase in corrosion potential rather than a decrease in current density. Furthermore, we examined the change in cationic concentration of $\mathrm{M}(\mathrm{M}=\mathrm{Cu}, \mathrm{Zr}$ and $\mathrm{Ti})$ in the surface of the film containing $\mathrm{Nb}{ }^{19)}$ With increasing $\mathrm{Nb}$ content, the cationic concentrations of $\mathrm{Zr}$, $\mathrm{Ti}$ and $\mathrm{Nb}$ in the surface film increase, while the $\mathrm{Cu}$ concentration decreases in comparison with each nominal concentration. These experimental data indicate that enrichment with $\mathrm{Zr}$, $\mathrm{Ti}$ and $\mathrm{Nb}$ plays a dominant role in the enhancement of corrosion resistance.

\section{Formation and Microstructure of Bulk Nanocrystal- Dispersed Glassy Alloys}

We examined the crystallization behavior of $\mathrm{Cu}_{60} \mathrm{Zr}_{30} \mathrm{Ti}_{10}$ and $\mathrm{Cu}_{60} \mathrm{Hf}_{30} \mathrm{Ti}_{10}$ glassy alloys. ${ }^{12,20)}$ The $\Delta T_{\mathrm{x}}$ was $37 \mathrm{~K}$ for the former alloy and $67 \mathrm{~K}$ for the latter, as shown in Fig. 6. The ordinary X-ray diffraction patterns showed a broad peak without any crystalline peak. ${ }^{20)}$ In addition, the ordinary radial distribution function showed a broad peak at the first nearest neighbor position for both alloys. However, as is evident from the environmental RDF curves around $\mathrm{Cu}$ and $\mathrm{Zr}$ atoms for the $\mathrm{Cu}_{60} \mathrm{Zr}_{30} \mathrm{Ti}_{10}$ glassy alloy shown in Fig. 8, the RDF curve around $\mathrm{Cu}$ consists of a broad peak at the first neighboring position, while the curve around $\mathrm{Zr}$ separates to two peaks consisting of $\mathrm{Zr}-\mathrm{Cu}$ and $\mathrm{Zr}-\mathrm{Zr}$ atomic pairs. This result indicates that elemental $\mathrm{Zr}$ and $\mathrm{Cu}$ are separated at the first neighboring position in the as-spun glassy phase. With the aim of clarifying the separated glassy structure, highresolution TEM images and selected-area electron diffraction patterns of the as-spun $\mathrm{Cu}_{60} \mathrm{Zr}_{30} \mathrm{Ti}_{10}$ and $\mathrm{Cu}_{60} \mathrm{Hf}_{30} \mathrm{Ti}_{10}$ alloys are shown in Fig. 9. ${ }^{12)}$ Very fine fringe-contrast regions with a size of about $5 \mathrm{~nm}$ are homogeneously dispersed in an isolated fashion in the glassy matrix and there is no appreciable difference in the dispersion nanostructures of the two alloys. Figure 10 shows the nanobeam electron diffraction patterns of the fringe contrast regions and their analytical results. All the reflection spots are analyzed as a cubic phase and its lattice parameter is $0.45 \mathrm{~nm}$ for the $\mathrm{Cu}_{60} \mathrm{Zr}_{30} \mathrm{Ti}_{10}$ alloy and $0.51 \mathrm{~nm}$ for the $\mathrm{Cu}_{60} \mathrm{Hf}_{30} \mathrm{Ti}_{10}$ alloy. The HAADF-STEM images of the two as-spun alloys are 


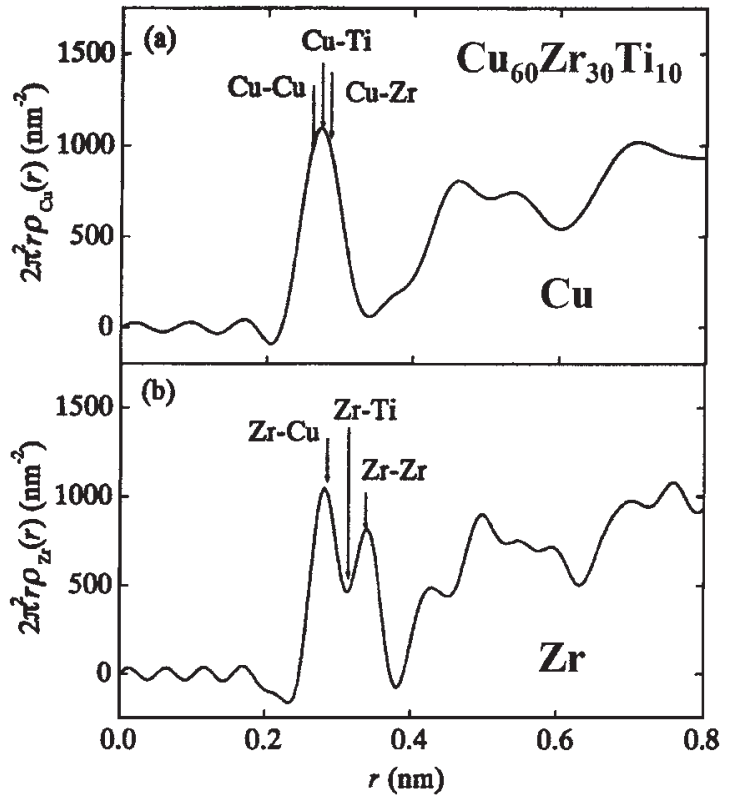

Fig. 8 Environmental radial distribution function (RDF) curves around $\mathrm{Cu}$ (a) and $\mathrm{Zr}$ (b) atoms for $\mathrm{Cu}_{60} \mathrm{Zr}_{30} \mathrm{Ti}_{10}$ glassy alloys.

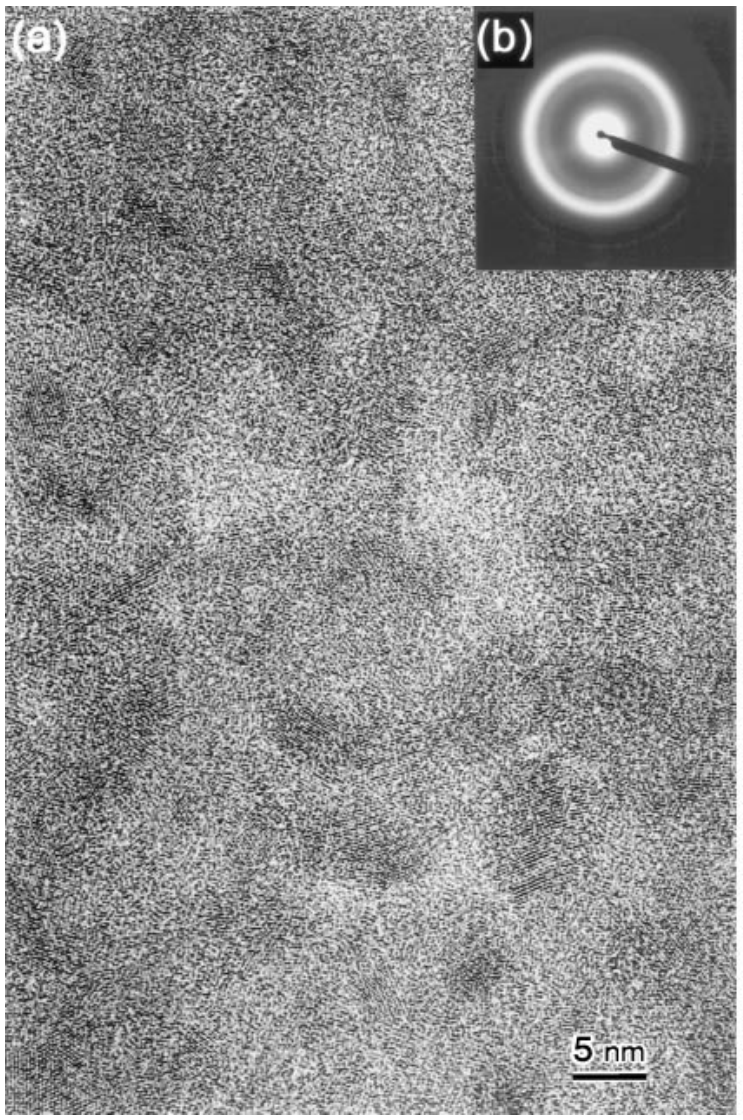

Fig. 9 High resolution TEM images and selected-area electron diffraction patterns of as-spun $\mathrm{Cu}_{60} \mathrm{Zr}_{30} \mathrm{Ti}_{10}(\mathrm{a}, \mathrm{b})$ and $\mathrm{Cu}_{60} \mathrm{Hf}_{30} \mathrm{Ti}_{10}(\mathrm{c}, \mathrm{d})$ glassy alloys.

shown in Fig. 11. ${ }^{21)}$ The bright contrast region with a size of $3-5 \mathrm{~nm}$ disperses homogeneously. Considering that the bright- and dark-contrast regions correspond to Zr-rich and $\mathrm{Cu}$-rich regions, respectively, it is concluded that the as-spun
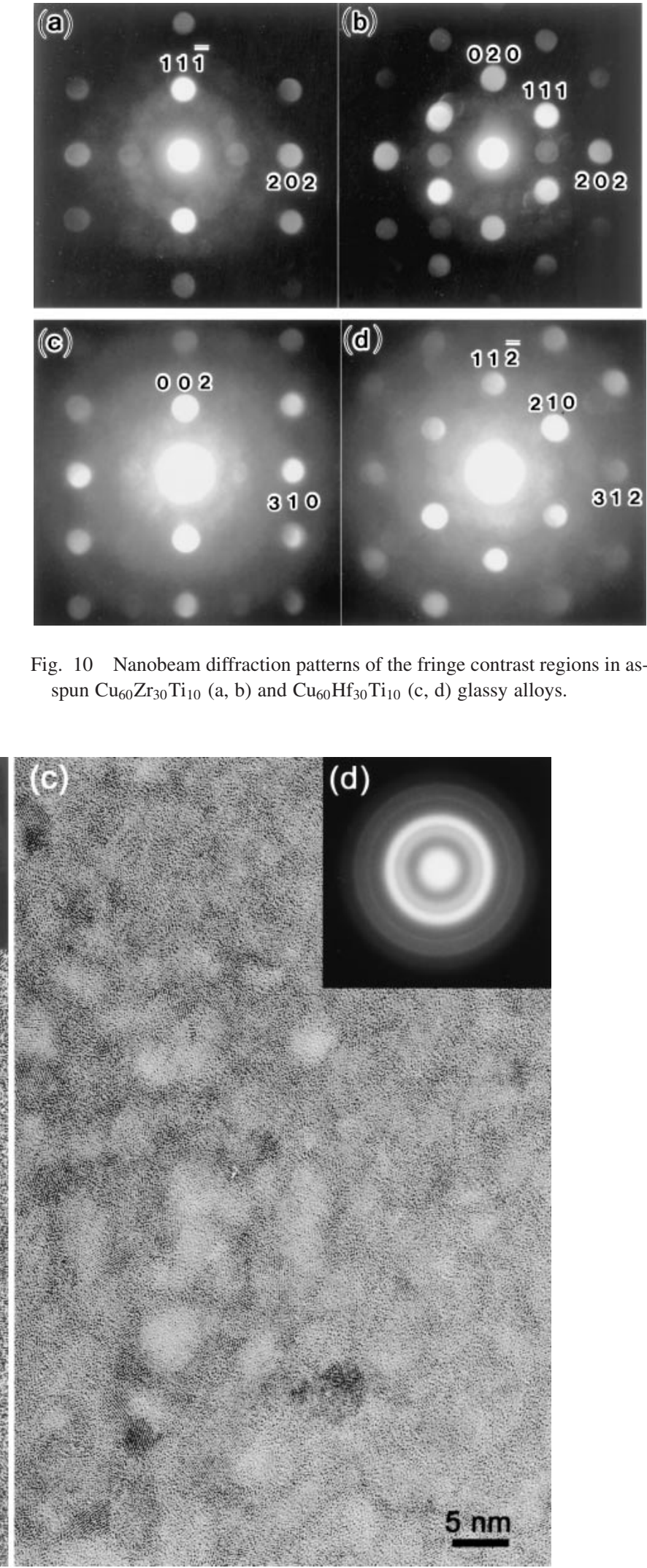

Fig. 10 Nanobeam diffraction patterns of the fringe contrast regions in asspun $\mathrm{Cu}_{60} \mathrm{Zr}_{30} \mathrm{Ti}_{10}(\mathrm{a}, \mathrm{b})$ and $\mathrm{Cu}_{60} \mathrm{Hf}_{30} \mathrm{Ti}_{10}(\mathrm{c}, \mathrm{d})$ glassy alloys.

alloys consist of a modulated structure consisting of $\mathrm{Zr}$ - and $\mathrm{Cu}$-rich regions. The Guineir plot of small angle X-ray scattering data of the as-spun $\mathrm{Cu}_{60} \mathrm{Hf}_{30} \mathrm{Ti}_{10}$ alloy has also indicated that the size of the modulated regions is approx- 


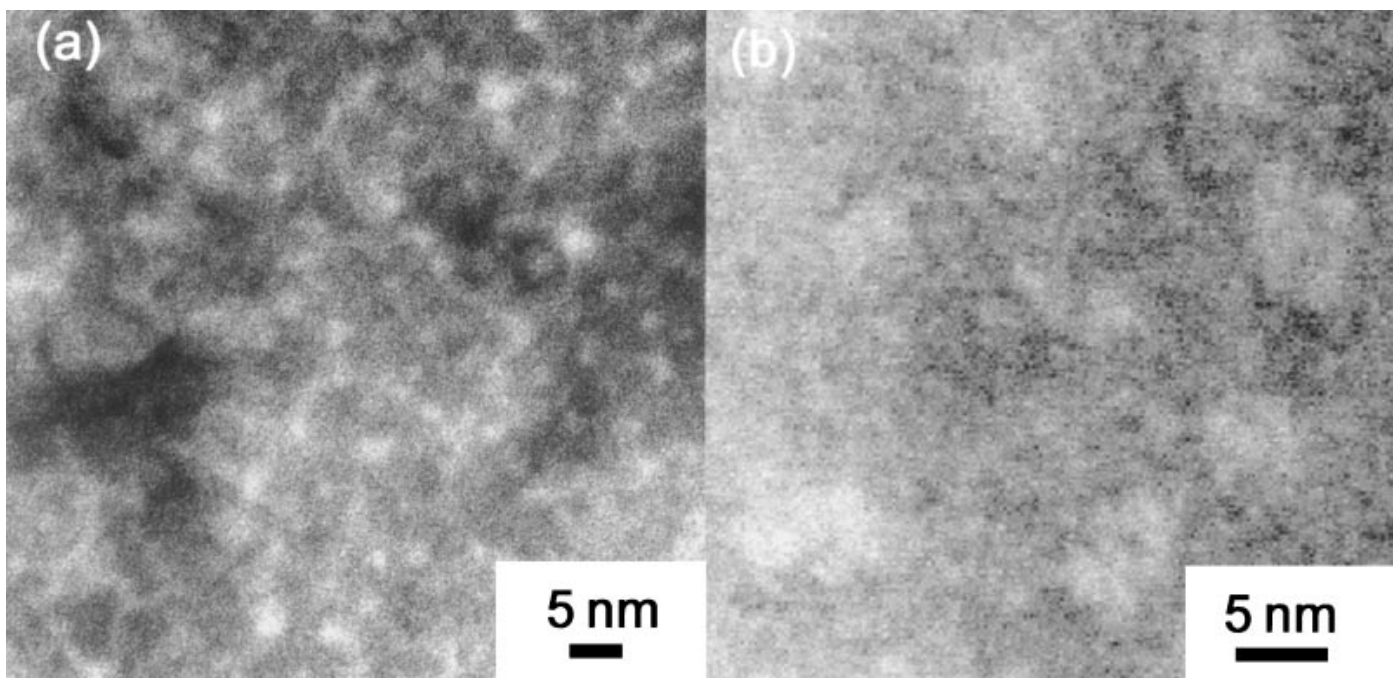

Fig. 11 HAADF-STEM images of as-spun $\mathrm{Cu}_{60} \mathrm{Zr}_{30} \mathrm{Ti}_{10}$ (a) and $\mathrm{Cu}_{60} \mathrm{Hf}_{30} \mathrm{Ti}_{10}$ (b) glassy alloys.

Table 1 Nanobeam EDX results of the melt-spun $\mathrm{Cu}_{60} \mathrm{Zr}_{30} \mathrm{Ti}_{10}$ (a) and $\mathrm{Cu}_{60} \mathrm{Hf}_{30} \mathrm{Ti}_{10}$ (b) alloys. (in at\%).

\begin{tabular}{|c|c|c|c|c|c|c|}
\hline & \multicolumn{3}{|c|}{ (a) } & \multicolumn{3}{|c|}{ (b) } \\
\hline & $\mathrm{Cu}$ & $\mathrm{Zr}$ & $\mathrm{Ti}$ & $\mathrm{Cu}$ & $\mathrm{Hf}$ & $\mathrm{Ti}$ \\
\hline \multirow{3}{*}{ Nanocrystal } & 67.7 & 26.5 & 5.8 & 68.8 & 26.8 & 4.4 \\
\hline & 70.9 & 24.4 & 4.7 & 69.0 & 25.5 & 5.5 \\
\hline & 65.7 & 28.3 & 6.0 & 64.4 & 29.8 & 5.8 \\
\hline \multirow{2}{*}{ Average } & 68.1 & 26.0 & 5.9 & 70.1 & 25.4 & 4.5 \\
\hline & 68.8 & 25.7 & 5.5 & 67.5 & 27.2 & 5.3 \\
\hline \multirow{5}{*}{ Glass } & 59.3 & 33.0 & 7.7 & 52.7 & 38.9 & 8.4 \\
\hline & 51.2 & 39.6 & 9.2 & 49.5 & 41.2 & 9.3 \\
\hline & 54.6 & 36.9 & 8.5 & 53.6 & 39.7 & 6.7 \\
\hline & 55.0 & 37.0 & 8.0 & 41.7 & 48.4 & 9.9 \\
\hline & 60.4 & 31.5 & 8.1 & 42.3 & 48.2 & 9.5 \\
\hline Average & 56.1 & 35.6 & 8.3 & 48.0 & 43.2 & 8.8 \\
\hline
\end{tabular}

imately 3-4 nm. ${ }^{21)}$ In addition, we analyzed alloy compositions of their modulated regions with $\mathrm{Zr}$ - and $\mathrm{Cu}$-rich compositions by nanobeam energy dispersion X-ray spectroscopy. ${ }^{21)}$ Table 1 summarizes the analytical alloy compositions of the fringe contrast (nanocrystal) region and the glassy regions for the as-spun $\mathrm{Cu}_{60} \mathrm{Zr}_{30} \mathrm{Ti}_{10}$ and $\mathrm{Cu}_{60} \mathrm{Hf}_{30} \mathrm{Ti}_{10}$ alloys. The nanocrystalline phase has a $\mathrm{Cu}$-rich, $\mathrm{Zr}$-(or Hf)poor and Ti-poor composition in comparison with the nominal alloy composition, while the glassy phase has a $\mathrm{Cu}$ poor, $\mathrm{Zr}$-(or Hf-)rich and Ti-rich composition. It is therefore concluded that the bright contrast region with $\mathrm{Zr}$ - or Hf-rich composition corresponds to the glassy region and the dark contrast region with a $\mathrm{Cu}$-rich composition consists of the nanocrystalline phase.

\section{Crystallization Behavior of Bulk Nanocrystal-Dis- persed Glassy Alloys}

It was shown that the $\mathrm{Cu}_{60} \mathrm{Zr}_{30} \mathrm{Ti}_{10}$ and $\mathrm{Cu}_{60} \mathrm{Hf}_{30} \mathrm{Ti}_{10}$ alloys in as-spun and as-cast states had a nanoscale mixed structure consisting of a cubic phase with a size of $3-5 \mathrm{~nm}$ embedded in a glassy matrix. The cubic phase has a lattice parameter of $0.45 \mathrm{~nm}$ for the former alloy and $0.51 \mathrm{~nm}$ for the latter, and a relatively $\mathrm{Cu}$-rich composition in comparison with the nominal composition. Figure 12 shows X-ray diffraction patterns of the $\mathrm{Cu}-\mathrm{Zr}-\mathrm{Ti}$ and $\mathrm{Cu}-\mathrm{Hf}-\mathrm{Ti}$ alloys annealed at temperatures just above the first exothermic peak. ${ }^{22)}$ We cannot detect any appreciable structural change for the former alloy, while the latter alloy shows a change to an orthorhombic $\mathrm{Cu}_{8} \mathrm{Hf}_{3}$ phase with $a_{0}=0.781 \mathrm{~nm}, b_{0}=$ $0.810 \mathrm{~nm}$ and $c_{0}=0.995 \mathrm{~nm}$. Figure 13 shows bright-field TEM images and selected-area electron diffraction patterns of the annealed alloys. The $\mathrm{Cu}-\mathrm{Zr}$-Ti alloy consists of two kinds of cubic phases with lattice parameters of $0.35 \mathrm{~nm}$ and $0.53 \mathrm{~nm}$. Considering that the cubic phase with $a_{0}=0.53 \mathrm{~nm}$ exists in the as-spun state, the first-stage exothermic peak is concluded to result from the precipitation of the cubic- $\mathrm{CuZr}$ phase with $a_{0}=0.35 \mathrm{~nm}$. The newly precipitated cubic-CuZr phase has a particle size of about $10-20 \mathrm{~nm}$ and disperses homogeneously in coexistence with the original cubic phase. However, we cannot detect distinct grain growth of the original cubic phase in the bright-field TEM image. In 


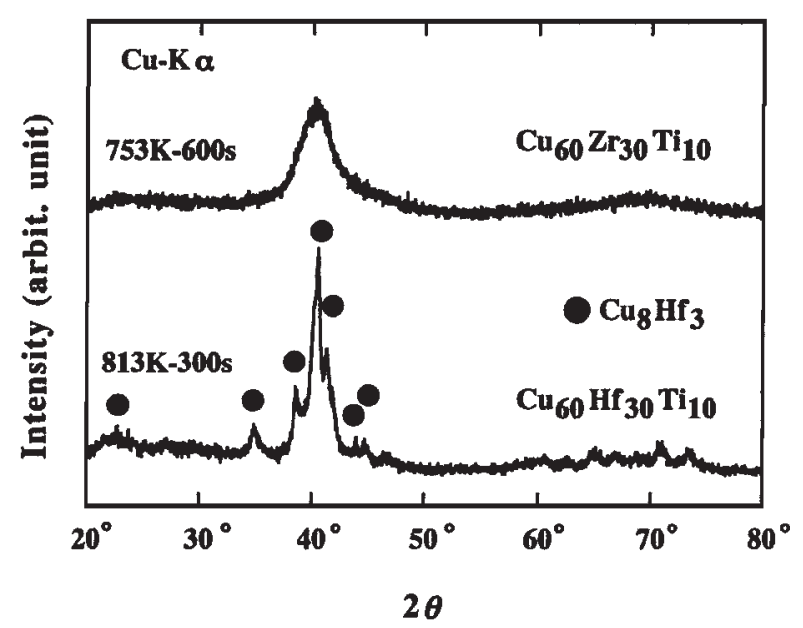

Fig. 12 X-ray diffraction patterns of the $\mathrm{Cu}_{60} \mathrm{Zr}_{30} \mathrm{Ti}_{10}$ and $\mathrm{Cu}_{60} \mathrm{Hf}_{30} \mathrm{Ti}_{10}$ glassy alloys annealed at the temperatures just above the first exothermic peak.

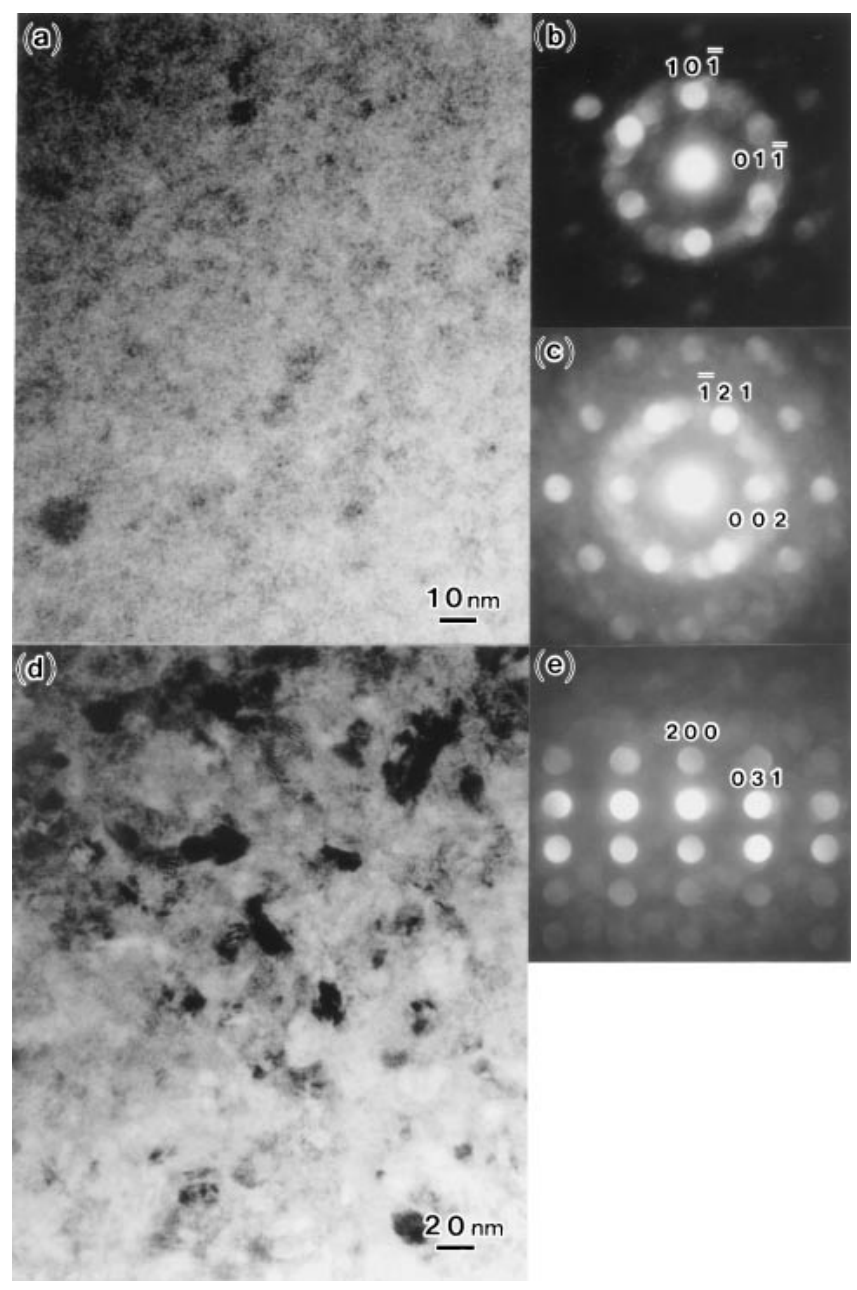

Fig. 13 Bright-field TEM images and nanobeam diffraction patterns of the $\mathrm{Cu}_{60} \mathrm{Zr}_{30} \mathrm{Ti}_{10}(\mathrm{a}, \mathrm{b}, \mathrm{c})$ and $\mathrm{Cu}_{60} \mathrm{Hf}_{30} \mathrm{Ti}_{10}(\mathrm{~d}, \mathrm{e})$ glassy alloys annealed at the temperatures just above the first exothermic peak.

contrast, the $\mathrm{Cu}-\mathrm{Hf}-\mathrm{Ti}$ phase is occupied by the $\mathrm{Cu}_{8} \mathrm{Hf}_{3}$ phase over the whole area and its grain size is about $20-30 \mathrm{~nm}$, which is much larger than that of the cubic phase. This result indicates clearly that the first exothermic peak of the $\mathrm{Cu}-\mathrm{Hf}$ -
Ti alloy is due to the precipitation of $\mathrm{Cu}_{8} \mathrm{Hf}_{3}$ phase.

We further examined the kinetic behavior of the precipitates by JMA plot analysis of the first exothermic peak corresponding to the precipitation of the cubic-CuZr and $\mathrm{Cu}_{8} \mathrm{Hf}_{3}$ phases. ${ }^{23)}$ A good linear relation was obtained in the JMA plots and the Avrami exponent ( $n$-value) was approximated as 2.5 for the precipitation of the cubic $\mathrm{CuZr}$ phase and 3.5 for the $\mathrm{Cu}_{8} \mathrm{Hf}_{3}$ phase. These $n$-values indicate that the precipitation occurs through the three-dimensional diffusion controlled growth of nuclei at a constant nucleation rate for the cubic $\mathrm{CuZr}$ phase and through the interface diffusion controlled growth with decreasing nucleation rate for the $\mathrm{Cu}_{8} \mathrm{Hf}_{3}$ phase. Thus, the kinetic behavior is significantly different between the two $\mathrm{Cu}$-based alloys. The Arrhenius analyses of incubation period, $\tau$ as a function of isothermal temperature, $T$, were also made for the primary cubic $\mathrm{CuZr}$ and $\mathrm{Cu}_{8} \mathrm{Hf}_{3}$ phases. ${ }^{23)}$ Good linear relations were recognized and the activation energy for the nucleation of the primary phase is evaluated to be $383 \mathrm{~kJ} / \mathrm{mol}$ for the $\mathrm{Cu}-\mathrm{Zr}$-Ti alloy and $443 \mathrm{~kJ} / \mathrm{mol}$ for the $\mathrm{Cu}-\mathrm{Hf}-\mathrm{Ti}$ alloy. The much larger activation energy for the $\mathrm{Cu}-\mathrm{Hf}-\mathrm{Ti}$ alloy indicates that the precipitation of the $\mathrm{Cu}_{8} \mathrm{Hf}_{3}$ phase is much more difficult as compared with the bcc $\mathrm{CuZr}$ phase, this being consistent with the difference in the precipitation modes. In addition, one can notice that the much larger supercooled liquid region for the $\mathrm{Cu}-\mathrm{Hf}-\mathrm{Ti}$ alloy originates from the difficulty of the precipitation of the primary $\mathrm{Cu}_{8} \mathrm{Hf}_{3}$ phase, as is evidenced from the different precipitation mode and the larger activation energy.

As shown in the previous section, the nanobeam EDX data indicate that the nanoscale bcc phase in the as-spun $\mathrm{Cu}_{60} \mathrm{Zr}_{30} \mathrm{Ti}_{10}$ and $\mathrm{Cu}_{60} \mathrm{Hf}_{30} \mathrm{Ti}_{10}$ alloys has $\mathrm{Cu}$-rich alloy compositions. Based on the experimental data, we have tried to form a glassy single phase through further optimization of alloy composition and confirmed that a decrease in $\mathrm{Cu}$ content as well as an increase in $\mathrm{Hf}$ content causes the formation of a glassy single phase.

\section{7. $\mathrm{Cu}-\mathrm{Zr}-\mathrm{Al}$ and $\mathrm{Cu}-\mathrm{Hf}-\mathrm{Al}$ Based Bulk Glassy Alloys}

It was shown that nanocrystal-dispersed bulk glassy alloys were formed in $\mathrm{Cu}-\mathrm{Zr}-\mathrm{Ti}$ and $\mathrm{Cu}-\mathrm{Hf}-\mathrm{Ti}$ alloy systems by the copper mold casting process. These ternary $\mathrm{Cu}$-based bulk glassy alloys do not completely satisfy the following three component rules ${ }^{1,2,4)}$ for stabilization of metallic supercooled liquid and formation of bulk glassy alloys, i.e., (1) multicomponent consisting of more than three elements, (2) significant atomic size mismatches above $12 \%$ among main constituent elements, and (3) negative heats of mixing among main elements. The deviation from the three component rules is thought to result in the formation of nanoscale crystaldispersed glassy alloys because of the increase in the stability of the supercooled liquid against crystallization. When the alloy component of these $\mathrm{Cu}$-based alloys is modified so as to satisfy the three component rules, it is strongly expected that the resulting $\mathrm{Cu}$-based alloys will have an enhanced glassforming ability through an increase in the stability of the supercooled liquid, i.e., through the extension of the supercooled liquid region prior to crystallization. We examined the thermal stability of $\mathrm{Cu}-\mathrm{Zr}$ - $\mathrm{Al}$ and $\mathrm{Cu}-\mathrm{Hf}-\mathrm{Al}$ ternary alloys in which the three component rules are satisfied. 


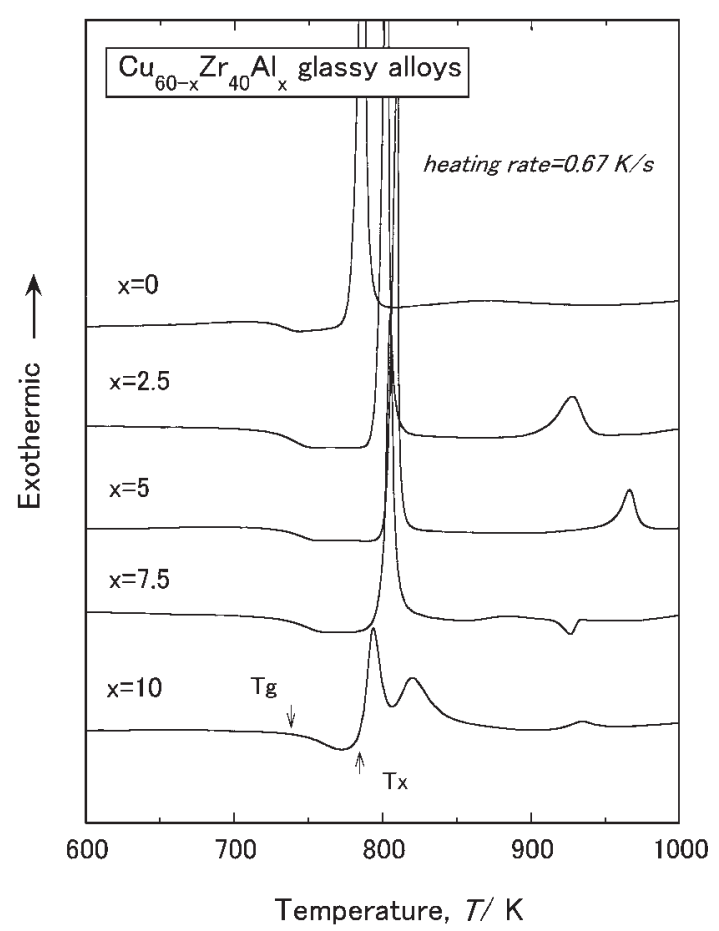

Fig. 14 DSC curves of melt-spun $\mathrm{Cu}_{60-x} \mathrm{Zr}_{40} \mathrm{Al}_{x}(x=0$ to 10 at $\%)$ glassy alloys.

Figure 14 shows DSC curves of the as-spun $\mathrm{Cu}_{60-x} \mathrm{Zr}_{40} \mathrm{Al}_{x}$ glassy alloys. The alloys containing $2.5-7.5 \% \mathrm{Al}$ exhibit a large supercooled liquid region prior to crystallization. A distinct composition dependence of $\Delta T_{\mathrm{x}}\left(=T_{\mathrm{x}}-T_{\mathrm{g}}\right)$ for the $\mathrm{Cu}-\mathrm{Zr}-\mathrm{Al}$ ternary glassy alloys is recognized and the largest $\Delta T_{\mathrm{x}}$ is $74 \mathrm{~K}$ for $\mathrm{Cu}_{55} \mathrm{Zr}_{40} \mathrm{Al}_{5}$ and $\mathrm{Cu}_{50} \mathrm{Zr}_{42.5} \mathrm{Al}_{7.5}$ alloys. Any deviation from these alloy compositions causes a gradual decrease in $\Delta T_{\mathrm{x}}$. However, it can be seen that large $\Delta T_{\mathrm{x}}$ values above $70 \mathrm{~K}$ are obtained over a rather wide composition range of $37.5-47.5 \% \mathrm{Zr}$ and $2.5-7.5 \% \mathrm{Al}$. High reduced glass transition temperatures above 0.60 are also obtained over a wide $\mathrm{Al}$ content range from $2-6 \% \mathrm{Al}$ in the alloy series of $\mathrm{Cu}_{60-x} \mathrm{Zr}_{40} \mathrm{Al}_{x}$ and the highest $T_{\mathrm{g}} / T_{1}$ is 0.62 for $\mathrm{Cu}_{55} \mathrm{Zr}_{40} \mathrm{Al}_{5}$. By choosing the $\mathrm{Cu}-\mathrm{Zr}$-Al alloys with high $T_{\mathrm{g}} / T_{1}$ above 0.60 , bulk glassy alloy rods with diameters up to at least $3 \mathrm{~mm}$ were formed by the copper mold casting process. ${ }^{24)}$ Table 2 summarizes thermal stability and mechanical properties of the $\mathrm{Cu}-\mathrm{Zr}$-Al bulk glassy alloys. These $\mathrm{Cu}$-based alloys possess high compressive fracture strength of 2100-2200 MPa with distinct plastic elongation of 0.0020.004. The fracture of the $\mathrm{Cu}$-based bulk glassy alloys
Cu-Hf-Al system

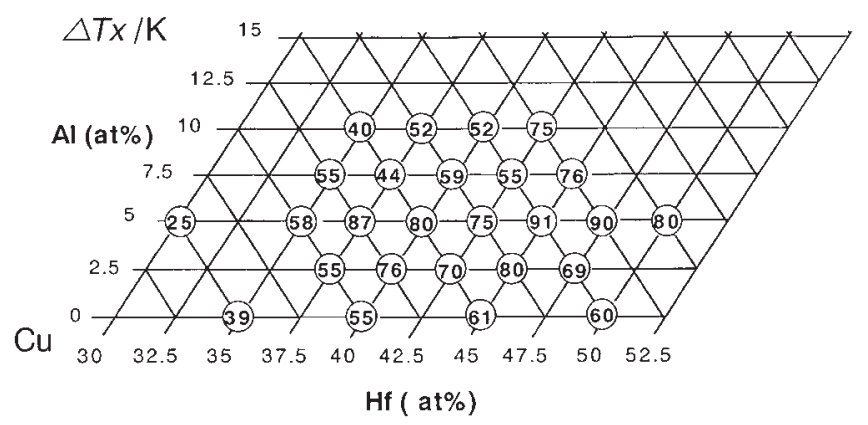

Fig. 15 Composition dependence of the supercooled liquid region, $\Delta T_{\mathrm{x}}\left(=T_{\mathrm{x}}-T_{\mathrm{g}}\right)$ for Cu-Hf-Al ternary glassy alloys.

occurred along a main shear band inclined by 43 degrees to the direction of applied stress, and a typical elongated vein pattern was observed in the fracture surface.

Similar thermal stability and mechanical properties were also obtained for $\mathrm{Cu}-\mathrm{Hf}-\mathrm{Al}$ ternary glassy alloys. Figure 15 shows the composition dependence of $\Delta T_{\mathrm{x}}$ for $\mathrm{Cu}-\mathrm{Hf}-\mathrm{Al}$ ternary glassy alloys. ${ }^{25)}$ The large $\Delta T_{\mathrm{x}}$ values above $80 \mathrm{~K}$ are obtained over a wide composition range of $37.5-50 \% \mathrm{Hf}$ and $2.5-5 \% \mathrm{Al}$ and the highest $\Delta T_{\mathrm{x}}$ value is $91 \mathrm{~K}$ for $\mathrm{Cu}_{50} \mathrm{Hf}_{45} \mathrm{Al}_{5}$. Thus, the $\Delta T_{\mathrm{x}}$ is strongly dependent on $\mathrm{Al}$ content. Table 2 also shows thermal stability and mechanical properties of the $\mathrm{Cu}-\mathrm{Hf}-\mathrm{Al}$ bulk glassy alloys. ${ }^{25)}$ These $\mathrm{Cu}-$ Hf-Al bulk glassy alloys exhibit very high compressive fracture strength of $2260-2370 \mathrm{MPa}$ with plastic strain of $0.002-0.006$, in addition to high $T_{\mathrm{g}} / T_{1}$ of $0.62-0.63$.

We further examined the additional effect of transition metals $(\mathrm{TM}=\mathrm{Pt}, \mathrm{Au}, \mathrm{Pd}$ or $\mathrm{Ag}$ ) on the thermal stability of supercooled liquid for $\mathrm{Cu}_{50} \mathrm{Zr}_{40} \mathrm{Al}_{5} \mathrm{TM}_{5}$ glassy alloys. The addition of $\mathrm{Au}$ or Pd increased $\Delta T_{\mathrm{x}}$ and the largest $\Delta T_{\mathrm{x}}$ was $85 \mathrm{~K}$ for the Pd-containing alloy. The extension of the supercooled liquid region results from a more significant increase in $T_{\mathrm{x}}$ in comparison with $\mathrm{Cu}_{55} \mathrm{Zr}_{40} \mathrm{Al}_{5}$ alloy. A quite remarkable effect on the $\Delta T_{\mathrm{x}}$ value was seen with the addition of $\mathrm{TM}$ elements to make $\mathrm{Cu}_{45} \mathrm{Hf}_{45} \mathrm{Al}_{5} \mathrm{TM}_{5}$ glassy alloys, as shown in Fig. 16. ${ }^{26)}$ All these glassy alloys have large $\Delta T_{\mathrm{x}}$ values above $93 \mathrm{~K}$ and the largest value is $110 \mathrm{~K}$ for the Ag-containing alloy. The increase in the $\Delta T_{\mathrm{X}}$ value for the Cu-Hf-Al-Ag alloy is due to the combination of the decrease in $T_{\mathrm{g}}$ and the increase in $T_{\mathrm{x}}$ in comparison with $\mathrm{Cu}_{50} \mathrm{Hf}_{45} \mathrm{Al}_{5}$ alloy. Thus, the additional effect of $\mathrm{Pd}$ and $\mathrm{Ag}$ leading to the increase of $\Delta T_{\mathrm{x}}$ is presumably due to an increase in the difficulty of atomic rearrangements on a long-

Table 2 Thermal stability and mechanical properties of $\mathrm{Cu}-\mathrm{Zr}-\mathrm{Al}$ and $\mathrm{Cu}-\mathrm{Hf}-\mathrm{Al}$ bulk glassy alloys.

\begin{tabular}{|c|c|c|c|c|c|c|c|}
\hline $\begin{array}{c}\text { Composition } \\
\text { (at } \%)\end{array}$ & $\begin{array}{c}T_{\mathrm{g}} \\
(\mathrm{K})\end{array}$ & $\begin{array}{l}\Delta T_{\mathrm{x}} \\
(\mathrm{K})\end{array}$ & $T_{\mathrm{g}} / T_{1}$ & $\begin{array}{c}\sigma_{\mathrm{c}, \mathrm{f}} \\
(\mathrm{MP})\end{array}$ & $\begin{array}{c}E \\
(\mathrm{GPa})\end{array}$ & $\begin{array}{l}\varepsilon_{\mathrm{c}, \mathrm{p}} \\
(\%)\end{array}$ & $H_{\mathrm{v}}$ \\
\hline $\mathrm{Cu}_{55} \mathrm{Zr}_{40} \mathrm{Al}_{5}$ & 723 & 74 & 0.62 & 2210 & 115 & 0.2 & 581 \\
\hline $\mathrm{Cu}_{50} \mathrm{Zr}_{45} \mathrm{Al}_{5}$ & 701 & 72 & 0.61 & 1885 & 102 & 0.0 & 546 \\
\hline $\mathrm{Cu}_{50} \mathrm{Hf}_{42.5} \mathrm{Al}_{7.5}$ & 781 & 55 & 0.63 & 2372 & 128 & 0.5 & 673 \\
\hline $\mathrm{Cu}_{52.5} \mathrm{Hf}_{40} \mathrm{Al}_{7.5}$ & 779 & 54 & 0.63 & 2344 & 125 & 0.6 & 661 \\
\hline $\mathrm{Cu}_{50} \mathrm{Hf}_{45} \mathrm{Al}_{5}$ & 763 & 91 & 0.62 & 2262 & 121 & 0.2 & 627 \\
\hline
\end{tabular}




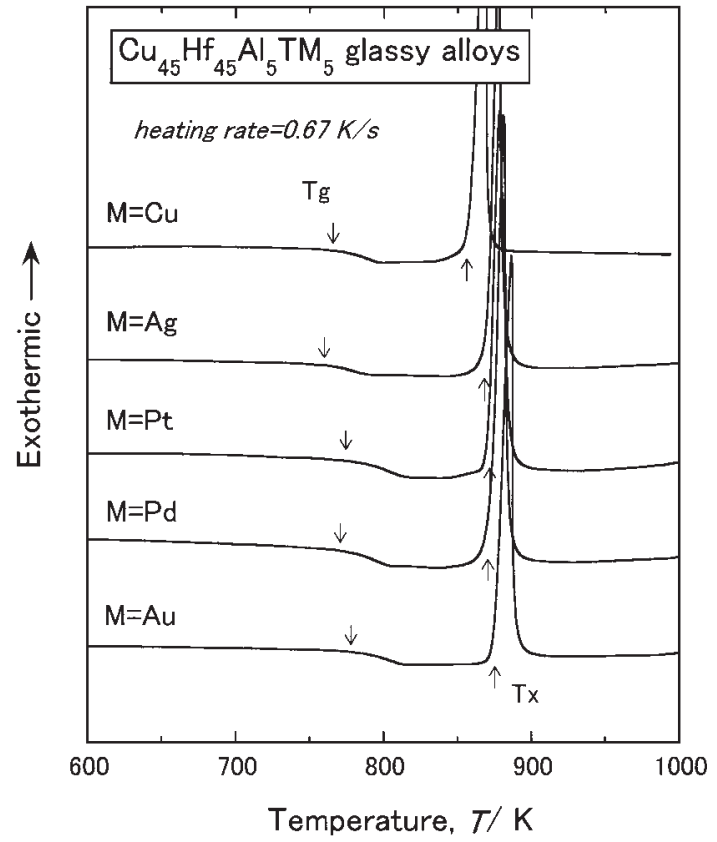

Fig. 16 DSC curves of melt-spun $\mathrm{Cu}_{45} \mathrm{Hf}_{45} \mathrm{Al}_{5} \mathrm{TM}_{5}(\mathrm{TM}=\mathrm{Ag}, \mathrm{Pt}, \mathrm{Pd}$ or $\mathrm{Au})$ glassy alloys.
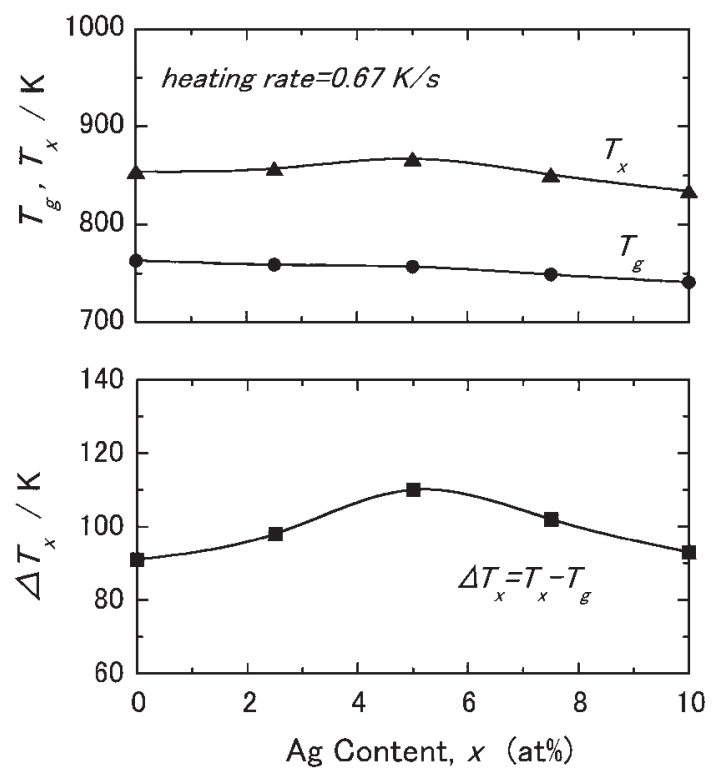

Fig. 17 Changes in $T_{\mathrm{g}}, T_{\mathrm{x}}$ and $\Delta T_{\mathrm{x}}$ as a function of $\mathrm{Ag}$ content for meltspun $\mathrm{Cu}_{50-x} \mathrm{Hf}_{45} \mathrm{Al}_{5} \mathrm{Ag}_{\mathrm{x}}$ ( $x=0$ to 10 at\%) glassy alloys.

range scale (necessary for the progress of crystallization from supercooled liquid with homogeneously mixed atomic configurations), in addition to an increase in the degree of satisfaction of the three component rules for stabilization of supercooled liquid. Figure 17 shows the changes in $T_{\mathrm{g}}, T_{\mathrm{x}}$ and $\Delta T_{\mathrm{x}}$ with $\mathrm{Ag}$ content for the $\mathrm{Cu}_{50-x} \mathrm{Hf}_{45} \mathrm{Al}_{5} \mathrm{Ag}_{\mathrm{x}}$ glassy alloys. ${ }^{26,27)}$ A large $\Delta T_{\mathrm{x}}$ above $100 \mathrm{~K}$ is obtained in the $\mathrm{Ag}$ content range of 5-7.5 at \%. In view of previous reports that metallic glassy alloys with large $\Delta T_{\mathrm{x}}$ above $100 \mathrm{~K}$ are limited to the $\mathrm{Zr}-\mathrm{Al}-\mathrm{Ni}-\mathrm{Cu}$ alloy system, the discovery of the new $\mathrm{Cu}-\mathrm{Hf}-\mathrm{Al}-\mathrm{Ag}$ and $\mathrm{Cu}-\mathrm{Hf}-\mathrm{Al}-\mathrm{Pd}$ glassy alloys is important for the future development of bulk glassy alloys from scientific and engineering points of view.

\section{Summary}

Glassy phase alloys were formed in $\mathrm{Cu}_{60} \mathrm{Zr}_{40}, \mathrm{Cu}_{45} \mathrm{Zr}_{55}$, $\mathrm{Cu}_{55} \mathrm{Hf}_{45}$ and $\mathrm{Cu}_{60} \mathrm{Hf}_{40}$ alloy rods with diameters up to $1.5 \mathrm{~mm}$. The replacement of $\mathrm{Zr}$ or Hf by $10 \mathrm{at} \% \mathrm{Ti}$ causes the formation of bulk glassy alloys containing nanoscale metastable cubic phase particles with a size of about $3-5 \mathrm{~nm}$ in cast alloy rods with diameters up to $4 \mathrm{~mm}$. The cubic phase has a lattice parameter of $0.45 \mathrm{~nm}$ for the former alloy and $0.51 \mathrm{~nm}$ for the latter. The critical diameter for the formation of such a nanostructure was $4 \mathrm{~mm}$ for both the alloys. The $E$, yield strength, $\sigma_{\mathrm{t}, \mathrm{f}}, \sigma_{\mathrm{c}, \mathrm{f}}$ and $\varepsilon_{\mathrm{c}, \mathrm{p}}$ are $114 \mathrm{GPa}, 1785 \mathrm{MPa}$, $2000 \mathrm{MPa}, 2150 \mathrm{MPa}$ and 0.012 , respectively, for the $\mathrm{Cu}-\mathrm{Zr}-$ Ti bulk alloy and $124 \mathrm{GPa}, 2040 \mathrm{MPa}, 2130 \mathrm{MPa}, 2160 \mathrm{MP}$ and 0.017 , for the $\mathrm{Cu}-\mathrm{Hf}-\mathrm{Ti}$ alloy. The addition of $\mathrm{Nb}$ caused an increase in corrosion resistance in various chemical aqueous solutions through the enrichment of elemental $\mathrm{Zr}$, Ti and $\mathrm{Nb}$ in the surface film. The $\Delta T_{\mathrm{x}}$ is $37 \mathrm{~K}$ for the $\mathrm{Cu}_{60} \mathrm{Zr}_{30} \mathrm{Ti}_{10}$ alloy and $67 \mathrm{~K}$ for the $\mathrm{Cu}_{60} \mathrm{Hf}_{30} \mathrm{Ti}_{10}$ alloy. The primary crystallization of the two nanocrystal-dispersed glassy alloys occurred by the precipitation of a cubic $\mathrm{CuZr}$ phase with a lattice parameter of $0.35 \mathrm{~nm}$ and an orthorhombic $\mathrm{Cu}_{8} \mathrm{Hf}_{3}$ phase, respectively. The grain size of their precipitates was $10-20 \mathrm{~nm}$ for the CuZr phase and $20-30 \mathrm{~nm}$ for the $\mathrm{Cu}_{8} \mathrm{Hf}_{3}$ phase. The $\mathrm{CuZr}$ phase precipitates through the three-dimensional diffusion-controlled growth of nuclei at a constant nucleation rate, while the $\mathrm{Cu}_{8} \mathrm{Hf}_{3}$ phase has the precipitation mode of interfacial diffusion-controlled growth of nuclei with decreasing nucleation rate. The difference in the precipitation modes is the origin of the difference in the stability of the supercooled liquid. The optimization of alloy components in Cu-based alloys so as to satisfy the three component rules caused the formation of a glassy single phase in $\mathrm{Cu}-\mathrm{Zr}-\mathrm{Al}$ and $\mathrm{Cu}-\mathrm{Hf}-\mathrm{Al}$ ternary systems. Their glassy single phase alloys also exhibit high $\sigma_{\mathrm{c}, \mathrm{f}}$ of 2100 $2370 \mathrm{MPa}$ with $\varepsilon_{\mathrm{c}, \mathrm{p}}$ up to 0.006 . Furthermore, the addition of a small amount of $\mathrm{Ag}$ or Pd increases $\Delta T_{\mathrm{x}}$ to over $100 \mathrm{~K}$, and the highest $\Delta T_{\mathrm{x}}$ value reaches as much as $110 \mathrm{~K}$. These new $\mathrm{Cu}$-based bulk glassy alloys with high glass-forming ability, large $\Delta T_{\mathrm{X}}$ of over $100 \mathrm{~K}$ and good mechanical properties are promising for the future development of bulk glassy alloys as a new type of structural material.

\section{REFERENCES}

1) A. Inoue: Mater. Trans., JIM, 36 (1995) 866-875.

2) A. Inoue: Mater. Sci. Forum. 179-181 (1995) 691-700.

3) W. L. Johnson: MRS. Bull. 24 (10) (1999) 42-56.

4) A. Inoue: Acta Mater. 48 (2000) 279-306.

5) X. H. Lin and W. L. Johnson: J. Appl. Phys. 78 (1995) 5614-4619.

6) A. Inoue, W. Zhang. T. Zhang and K. Kurosaka: Mater. Trans. 42 (2001) 1149-1151.

7) A. Inoue, W. Zhang, T. Zhang and K. Kurosaka: Acta Mater. 49 (2001) 2645-2652.

8) A. Inoue and W. Zhang: Mater. Trans. 45 (2004) 584-587.

9) A. Inoue, W. Zhang, T. Zhang and K. Kurosaka: J. Mater. Res. 16 (2001) 2836-2844.

10) A. Inoue, W. Zhang, T. Zhang and K. Kurosaka: Mater. Trans. 42 (2001) 1805-1812.

11) Y. Chen, T. Zhang, W. Zhang, D. Ping, K. Hono, A. Inoue and T. Sakurai: Mater. Trans. 43 (2002) 2647-2650.

12) M. Kasai, J. Saida, M. Matsushita, T. Osuna, E. Matsubara and A. Inoue: J. Phys.: condens. Matter 14 (2002) 13867-13877. 
13) J. Saida, N. Matsushita and A. Inoue: Mater. Trans. 43 (2002) 19371946.

14) D. V. Louzguine and A. Inoue: Scr. Mater. 48 (2003) 1325-1329.

15) K. Saksl, H. Franz, P. Jóvári, K. Klementiev, E. Welter, A. Ehnes, J. Saida, A. Inoue and J. Z. Jiang: Appl. Phys. Lett. 83 (2003) 3924-3926.

16) A. Inoue, T. Zhang K. Kurosaka and W. Zhang: Mater. Trans. 42 (2001) 1800-1804.

17) T. Zhang, T. Yamamoto and A. Inoue: Mater. Trans. 43 (2002) 3222 3226.

18) T. Yamamoto, C. Qin, T. Zhang, K. Asami and A. Inoue: Mater. Trans. 44 (2003) 1147-1152.

19) C. Qin, K. Asami, T. Zhang, W. Zhang and A. Inoue: Mater. Trans. 44
(2003) 749-753.

20) K. Uematsu, Master Thesis, Tohoku University, 2002.

21) J. Saida, T. Osuna, A. Inoue and M. Ohnuma: J. Mater. Res. 18 (2003) 2013-2016.

22) M. Kasai, E. Matsubara, J. Saida, M. Nakayama, K. Uematsu, T. Zhang and A. Inoue: Mater. Sci. Eng. in press.

23 J. Saida, T. Osuna, M. Ohnuma, E. Matsubara and A. Inoue: Sci. Tech. Adv. Mater. 4 (2003) 311-318.

24) A. Inoue and W. Zhang: Mater. Trans. 43 (2002) 2921-2925.

25) A. Inoue and W. Zhang: J. Mater. Res. 18 (2003) 1435-1440.

26) A. Inoue and W. Zhang: Appl. Phys. Lett. 83 (2003) 2351-2353.

27) W. Zhang and A. Inoue: Mater. Trans. 44 (2003) 2921-2925. 